Antoanela Marta MARDAR

„Dunărea de Jos” University of Galați

\title{
A COMPARATIVE - CONTRASTIVE APPROACH TO AUXILIARY VERBS IN ENGLISH, ROMANIAN AND ITALIAN
}

Auxiliary verbs represent a very useful tool in any language, their main function being that of helping speakers provide relevant information about the time and the nature of the action they make reference to in communication.

Depending on the languages taken into consideration, the typology and number of auxiliary verbs used in communication in order to individualize the action expressed by speakers differs significantly. If we consider the three languages approached in the present paper, i.e. English, Romanian and Italian, the list of auxiliary verbs proper includes five verbs in English, three in Romanian and two in Italian:

\begin{tabular}{|c|c|}
\hline English & to do, to be, to have, will, would \\
\hline Romanian & a fi, a avea, a vrea \\
\hline Italian & essere, avere \\
\hline
\end{tabular}

For the sake of relevance, focus will be laid only on the formal and semantic characteristics of the two auxiliaries shared by these languages.

The auxiliary verbs to be and to have are used in English as marks of an important verb category, namely aspect, which is both formally and semantically traceable in the verb form. The auxiliary verb to be is a mark of the continuous or progressive aspect in English, which means that it is an obligatory element to be used with all the finite and non-finite forms of the verb in this aspect (e.g. Present Tense Continuous, Past Tense Continuous, Future Tense Continuous, Future in the Past Continuous, Present Conditional Continuous and Present Infinitive Continuous). A formal aspect worth mentioning at this point is that the auxiliary verb to be always requires the present participle of the main verb. On the other hand, the auxiliary verb to have is a mark of the perfect or perfective aspect in English, which means that it is part and parcel of all the perfect tenses in this language (e.g. Present Perfect Simple, Past Perfect Simple, Future Perfect Simple, Future Perfect in the Past Simple, Perfect Conditional Continuous, Perfect Infinitive and Perfect Gerund). Similarly to the auxiliary verb to be, 
to have conditions the form of the immediately following verb which has to be in the past participle. The continuous and the perfective aspects coexist a series of verb forms in English which, as their names suggest, bring together the auxiliary verbs to be and to have: Present Perfect Continuous, Past Perfect Continuous, Future Perfect Continuous, Future Perfect in the Past Continuous, Perfect Conditional Continuous, and Perfect Infinitive Continuous.

The formal value of auxiliary verbs is obvious in Romanian and Italian, as well, this aspect being highlighted in the definitions provided by the specialists in the field. Referring to auxiliary verbs, Dumitru Irimia (1997) states that such verbs lack any semantic content and have a strict use with specific tenses. Their forms, when used as auxiliaries, differ from their forms when used as main verbs:

"Auxiliarele morfologice în limba română sunt verbe golite de conținut semantic și fixate in anumite forme flexionare. Flexiunea lor - redusă, de obicei, la o singura paradigmă temporală - este de cele mai multe ori diferită de flexiunea acelorasi verbe în conditia de verbe libere." (Irimia 1997: 184)

Moreover, he underlines that auxiliaries are included in the category of free morphemes used in Romanian to express specific grammatical meaning together with other auxiliaries: "Verbele auxiliare fac parte din categoria morfemelor libere de care se serveste limba română pentru exprimarea unor sensuri gramaticale fine alături de alte auxiliare ale flexiunii." (Irimia 1997: 184)

As regards the definition of auxiliary verbs in Italian, their formal value is most often the aspect pointed out by different specialists in the field because these verbs are linguistic tools which 'help' in forming compound tenses. Marinucci (1996: 195) emphasizes this idea when he states that " $i$ verbi ausiliari intervengono in "aiuto" nella formazione dei tempi composti di tutti $i$ verbi". Using the formal value of auxiliary verbs as a starting point in his approach, Serriani (1989) considers that such verbs can provide relevant information, about such verb categories as voice and tense (auxiliaries proper), about a specific semantic value (verbi servili) or an aspectual element (verbi fraseologici) :

"Ausiliari sono tutti quelli verbi che, accanto a un loro uso e significato autonomi, svolgono funzione vicaria nei confronti di qualsiasi altro verbo individuando: a) una determinazione morfologica (diatesi o tempo: ausiliari propriamente detti); b) un particolare valore semantico (servili); un datto elemento aspettuale (fraseologici Moretti-Orvieto 1983: 12-13)" (Serriani 1989: 391) 
An interesting aspect mentioned by the Italian grammarians is the fact that the two auxiliaries combine only with specific classes of main verbs, i.e. avere is used with transitive verbs and essere combines with intransitive and pronominal verbs, and with transitive verbs, if they are in the passive voice:

"I verbi ausiliari intervengono in "aiuto" nella formazione dei tempi composti di tutti $i$ verbi. L'ausiliare avere viene usato per formare $i$ tempi composti di tutti $i$ verbi transitivi, con l'ausiliare essere si coniugano tutti i verbi transitivi alla forma passiva e $i$ verbi pronominali. Per i verbi intransitivi non è possibile codificare una regola precisa riguardo alla scelta dell' ausiliare." (Marinucci 1996: 195)

Similarly to the auxiliary verbs to $b e$ in English and $a$ fi in Romanian, essere is used in Italian as a mark of the passive voice.

"Essere e avere consentono la formazione dei tempi composti con valore di passato rispettivamente a) per la maggioranza dei verbi intransitivi, per quasi tutti i verbi impersonali, per tutti quelli riflessivi e intransitivei pronominali b) per tutti i verbi transitivi e per un certo numero di intransitivi. Il verbo essere forma inoltre il passivo." (Serriani 1989: 391)

Moving from the formal to the semantic characteristics of the verbs to be / a fi / essere and to have / a avea / avere, reference should be made that their use as auxiliaries, when they are devoid of any meaning, is in full opposition with the instances when they function as main verbs. The verbs to be and to have are the two most common 'state verbs' in English used to express 'states of affairs' or situations valid at a given moment in time. When used with this semantic value, both verbs take only the simple/indefinite aspect of the tense required by the context:

e.g. Jane is not at home now. You can try to call her later.

Their parents have too many financial problems at present.

The same grammatical behaviour may be observed when the verb to $\boldsymbol{b} \boldsymbol{e}$ is a semi-auxiliary (copulative/link verb, part of a nominal predicate) used to express a permanent characteristic of the subject and when the verb to have (main verb) expresses possession:

e.g. Your sister is intelligent and everybody likes her.

Jack has a lovely Ferrari Testarossa. It must have cost him a fortune.

Comparing English and Romanian, the verbs $\boldsymbol{a}$ fi and $\boldsymbol{a}$ avea are used as main verbs to express existence and possession, respectively:

e.g. Ziarul este pe masă. (a se afla)

Nu este nici o altă solutie (a exista)

Ioana are o casă si două masini. (a poseda) 
In much the same way, the verb essere is used as a main verb in Italian with the meaning 'to exist' ('essistere', 'trovarsi') and avere with meanings such as : 'to possess', 'to feel', 'to obtain', 'to receive': "Avere è usato con valore predicativo con vari significati: possedere, sentire, provare ('avere compassione per qualcuno'), ottenere (avere dei risultati), ricevere (avere notizie)" (Marinucci 1996: 196). The examples below are relevant in this respect:

\section{e.g. Il telefono è nella tua stanza. (trovarsi)}

Non c'è niente da fare in questa situazione (esistere)

Gianni ha tutto quello che vuole (possedere)

Ha tanta compassione per i bambini malati (provare)

Tu hai dei risultati migliori questo semestre. (ottenere)

Non ho notizie da Maurizio da quasi due settimane. (ricevere)

Although the verbs to be and to have are obviously devoid of any meaning when used as auxiliaries, their being marks of the continuous and perfective aspect, respectively, in English allow for a correlation between the presence of these auxiliaries in the verb form and the type of action expressed. Thus, the continuous aspect is formally marked by the auxiliary verb to be and the present participle of the main verb and it is commonly used in English to express actions in full progress, durative actions or temporary actions/situations. It is also associated with changing situations or with modality (the speakers' attitude towards the message conveyed). As regards the perfect/ perfective aspect, it formally implies the presence of the auxiliary verb to have and of the past participle for the immediately following verb. This aspect it is used by speakers when reference has to be made to a past (completed) action, situation or event. Some of the various meanings conveyed by the continuous aspect in English are exemplified by a series of relevant examples included in the table below:

\begin{tabular}{|l|l|}
\hline \multicolumn{2}{|c|}{ THE CONTINUOUS ASPECT $\rightarrow$} \\
\hline $\begin{array}{l}\text { actions in } \\
\text { full progress }\end{array}$ & $\begin{array}{l}\text { The baby is sleeping so we should turn off the TV. (action } \\
\text { in full progress at the moment of speaking) } \\
\text { Jane was attending a conference this time last week. } \\
\text { (action which was in full progress at a given moment } \\
\text { in the past) } \\
\text { The new employees will be working when you get to work } \\
\text { tomorrow morning. (action which will be in progress at } \\
\text { a given moment in the future when another action } \\
\text { happens) }\end{array}$ \\
\hline
\end{tabular}




\begin{tabular}{|l|l|}
\hline $\begin{array}{l}\text { durative } \\
\text { actions }\end{array}$ & $\begin{array}{l}\text { My father was working all day long yesterday. } \\
\text { They have been jogging for almost two hours. } \\
\text { We will be discussing the terms of the contract between 9 } \\
\text { and 11 tomorrow morning. }\end{array}$ \\
\hline $\begin{array}{l}\text { temporary } \\
\text { actions }\end{array}$ & $\begin{array}{l}\text { Our manager is working longer hours this week. (only } \\
\text { this week) } \\
\text { Jackie hasn't been studying too hard lately. (she } \\
\text { normally studies hard) } \\
\text { The children were going to bed later those days. (only } \\
\text { those days) }\end{array}$ \\
\hline
\end{tabular}

Regarding Romanian and Italian, the auxiliary verbs analyzed have strictly a formal value in these languages. They are used to form various compound tenses, but they do not express any of the semantic values associated with to be and to have as marks of the continuous and perfective aspects in English. This idea is pointed out by Dumitru Irimia (1997) who states that the grammatical category of tense includes relevant information about the categories of aspect and mood, as well as about person and number:

„În limba română categoria gramaticală a timpului înglobează în desfăsurarea opozitiilor sale interne si categoriile gramaticale aspect si mod intr-un process de solidarizare în parte asemănător $\mathrm{cu}$ cel propriu complementaritătii categoriilor de persoană si număr." (Irimia 1997: 211)

Enlarging on the category of aspect, Irimia explains that this category is illustrated in Romanian by the opposition perfective/imperfective, the former being associated with complete actions and the latter with incomplete ones: Categoria gramaticală a aspectului se dezvoltă în limba română prin opozitia dintre 2 termeni corelativi: pefectiv/ imperfectiv. Opozitia perfectiv imperfectiv se corelează cu opozitia împlinit -neîmplinit." (id. ibid.)

Another interesting aspect pointed out is that the grammatical category of aspect is expressed in various ways in Romanian depending on the tense, mood and voice envisaged and in close interdependence with the semantic content of the main verbs. The past tenses of the indicative mood are the best to illustrate the perfective - imperfective opposition. The tenses perfectul compus, perfectul simplu and mai mult ca perfectul are used for completed actions and imperfectul is selected when reference has to be made to incomplete actions: 
Categoria gramaticală a aspectului se realizează in mod diferit în functie de timp, mod si diateză precum si in strânsă legătură cu continutul semantic al verbelor. Opozitia cea mai bine reprezentată caracterizează timpul trecut indicativ. (Irimia 1997: 212)

The perfective- imperfective dichotomy is integrated by Dumitru Irimia (1997) in the subjective aspect (aspectul subiectiv) which represents a means of modalizing the temporal characteristics of the verbal action. Moreover, reference is also made to the objective aspect which is selected by speakers in order to provide relevant information about the development of the action or about its specific stages traceable in verb form. From this perspective, mention may be made of the singular, plural, imminent inchoative, continuing or ending character of an action:

"Se disting două variante ale categoriei gramaticale aspect: 1. aspectul subiectiv expresia modului specific de înscriere de către vorbitor a temporalitătii actiunii verbale in durata enuntării si 2. aspectul obiectiv - expresia modului specific de desfăsurare obiectivă a actiunii verbale în durata enuntului. Prin aspectul subiectiv subiectul vorbitor modalizează temporalitatea actiunii verbale pe care o poate prezenta ca perfectivă (Am traversat repede strada sau imperfectivă Când traversam strada m-a strigat cineva). Prin aspectul obiectiv, subiectul vorbitor descrie modul de desfãsurare sau momente, etape in desfăsurarea actiunii verbale în planul enuntului: singularitate (a citi), pluralitate (a reciti), iminent (stă să adoarmă), incoativ (a adormi), continuativ (a dormi) sau terminativ (a termina de dormit)" (Irimia 1997: 212)

Combining the elements included in the classification of aspect suggested by Dumitru Irimia, Gabriela Pană Dindelegan (2010) states that this category expresses the change of state visible in the verb form from the point of view of its development:

"Aspectul prezintă schimbarea de stare desemnată de verb din punctul de vedere al desfäsurării sale care poate fi văzută:

- ca un eveniment unic, de obicei de scurtă durată (aspect punctual sau momentan - ea deschide) sau ca aflat în desfăsurare, într-un interval mai îndelungat (aspect durativ sau continuu - a se plimba)

- ca încheiată (aspectul perfectiv - a căzut) sau neîncheiată (aspect imperfectiv cădea)

- ca petrecându-se o singură dată (a închis) sau ca repetându-se (închidea mereu) (aspect iterativ)

- ca fiind în pregătire (aspect prospectiv - stă să plouă), în curs de a începe (aspect incoativ - începe să mănânce), în desfăsurare (aspect continuativ - continua să cânte) sau în curs de terminare (aspect terminativ - termină de cântat)." (Dindelegan 2010: 243-244)

As far as the Italian approach to the category of aspect is concerned, Serriani (1989) underlines that this verb category provides information 
regarding the duration, momentary character, repeatedness, beginning or completion of an action: L'aspetto contrassegna l'atto verbale secondo la prospettiva della durata, della momentaneità, della ripetitività, dell'inizio o della conclusione di un processo, della compiutezza o dell' incompiutezza dell'azione. (Serriani 1989: 390)

A similar view is expressed by Marinucci (1996) who states that 'aspectual auxiliaries' are used in Italian to denote the beginning of an action, actions on the point of starting, actions in progress and durative or completed actions:

"Gli ausiliari aspettuali esprimono i seguenti significati:

- azione che inizia (aspetto ingressivo puntuale) cominciare, mettersi, iniziare

- azione che sta per iniziare (aspetto ingressivo imminente) stare per, accingersi

- azione che si svolge e dura nel tempo (aspetto durativo) stare + gerundio, continuare a, insistere nel

- azione che termina (aspetto conclusivo puntuale) smettere, cessare, finire di “ (Marinucci 1996: 199)

Taking into discussion the same class of verbs, Serriani (1989) makes explicit reference to the formal and semantic characteristics of 'aspectual auxiliaries': "Gli ausiliari di tempo o aspettuali segnalano, in unione con un altro verbo di modo indefinito (infinito o gerundio, un particolare aspetto dell'azione: imminenza, inizio, continuità o conclusione di un'azione". (Serriani 1989: 397) This opinion is shared by Trifone and Palermo (2000) who state that the category of aspect may be expressed in different ways in Italian, either formally, or semantically:

L'italiano, a differenza di altre lingue, [...] non dispone di desinenze verbali che consentano di determinare il valore aspettuale del verbo. Tuttavia, ciascun verbo può esplicitare il suo valore aspettuale in più modi:

- attraverso il significato intrinseco: esistono verbi come cadere, morire, colpire, che esprimono un'azione momentanea; altri come dormire, abitare, studiare che esprimono un'azione durativa; altri ancora come maturare, impallidire, arrosire, che esprimono un'azione che si compie progressivamente, ecc.

- attraverso il tempo: alcuni tempi verbali hanno uno specifico valore aspettuale. Se l'azione viene presentata come conclusa nel passato, si ha aspetto perfettivo; se l'azione viene presentata nel corso del suo svolgimentosi ha aspetto imperfettivo. Inoltre, le frasi Scrivo una lettera e Sto scrivendo una lettera esprimono, rispettivamente, un'azione durativa o progressiva.

- attraverso perifrasi verbali: essere sul punto di, essere in procinto di, stare per+ infinito del verbo esprimono l'aspetto ingressivo o incoativo;

- attraverso strumenti derivativi: alcuni suffissi come -icchiare, -acchiare, -ettare, -ottare, -erellare conferiscono al verbo di base un particolare significato aspettuale: 
cantare $\rightarrow$ canticchiare, rubare $\rightarrow$ rubacchaire, fischiare $\rightarrow$ fischiettare, parlare $\rightarrow$ parlottare, giocare $\rightarrow$ giocherellare. (Trifone, Palermo 2000: 117)

To conclude, the idea should be pointed out that auxiliary verbs have the same grammatical function in the three languages taken into account in the present paper. They are used to form compound tenses and are the elements in the predicate which provide relevant information about verb categories such as voice, mood, tense, person and number. As far as the category of aspect is concerned, it is obvious that this category is represented differently in English, Romanian and Italian. If the continuous and perfective aspects are formally and semantically marked in English, a matrix being easy to suggest in this respect, they are expressed mostly by lexical means in Romanian and Italian, the repetitive, durative, momentary, (in)complete nature of the action being traceable mostly in the meaning of the main verb and in the specific grammatical constructions used to express some of these aspectual values (Dindelegan 2010, Dardano e Trifone 1995):

Aspectualitatea se îndică în mare măsură prin mijloace lexicale: prin constructii cu verbe având sens aspectual care alcătuiesc împreună cu verbul principal un predicat complex, prin circumstantiale si prin particule adverbiale. Gramaticile românesti mai vechi nu includeau aspectul între categoriile verbului deoarece în română acesta nu este marcat cu mijloace grammatical specifice. Timpurile verbale marchează în limba română doar anumite valori aspectuale aspectul perfectiv/imperfectiv, aspectul momentan/durativ si aspectul iterativ. Mijloacele de marcare a aspectului interferează cu trăsăturile aspectuale inerente ale sensului lexical al verbului. Verbele pot fi preponderant durative (a rătăci, a creste, a astepta) sau punctuale (a apărea, a adormi). Aparitia lor la timpuri durative sau punctuale întăreste sau contrazice semnificatia primară, creând efecte de sens contextuale. (Dindelegan 2010: 243-244)

In italiano l'aspetto non è grammaticalizzato, ciò nonostante, le principali nozioni aspettuali sono riconoscibili nel Sistema della flessione verbale. Aspetto perfettivo, aspetto imperfettivo, aspetto compiuto, aspetto progressivo. (Dardano e Trifone 1995: $315-316)$

Nevertheless the formal specificity of auxiliary verbs shared by the three languages under discussion and the fact that the their semantic values in English find an equivalent semantic representation in Romanian and Italian are elements which may prove extremely useful in teaching and learning auxiliary verbs to philology students, irrespective of the students' native language. 


\section{REFERENCES:}

Dardano Maurizio, Trifone Piero, Grammatica italiana con nozioni di linguistica, Zanichelli Editore, Milano, 1995.

Irimia Dumitru, Gramatica limbii române. Morfologie. Sintaxă, Editura Polirom, Iaşi, 1997.

Marinucci Marcello, La lingua italiana. Grammatica, Edizioni Scolastiche Bruno Mondadori, Torino, 1996.

Moretti Giovanni Battista, Orvietto Giorgio Rafaele, Grammatica italiana, vol III Il verbo: morfologia e note generali di sintassi, Benucci, Peruggia, 1983.

Pană Dindelegan Gabriela (coord.), Gramatica de bază a limbi române, Editura Univers Enciclopedic Gold, Bucureşti, 2010.

Serianni Luca, Grammatica italiana. Italiano comune e lingua letteraria, Utet Libreria, Torino, 1989.

Trifone Pietro, Palermo Massimo, Grammatica italiana di base, Zanichelli Editore, Bologna, 2000.

Abstract: Starting from the fact that auxiliary verbs have the same grammatical function, irrespective of the language taken into consideration, the present paper aims at identifying relevant formal and semantic similarities and dissimilarities between the most common auxiliary verbs in English, Romanian and Italian and at proving that certain semantic features shared by the auxiliary verbs analyzed (to be and to have) may represent a useful tool for teaching English auxiliary verbs to Romanian and/or Italian students.

Key words: auxiliaries, duration, perfectivity, progress. 